\title{
Rekayasa Lalu Lintas Pada Kawasan Simpang Jl. Lingkar Tengah - Jl. Dr. Leimena Di Kota Makassar
}

\author{
Mellyarti $^{1, a}$ dan Zulkifli ${ }^{2, b}$ \\ ${ }^{1}$ Mahasiswa Jurusan Teknik Sipil Program Studi D4 Jasa Konstruksi Politeknik Negeri Ujung Pandang \\ ${ }^{2}$ Mahasiswa Jurusan Teknik Sipil Program Studi D4 Jasa Konstruksi Politeknik Negeri Ujung Pandang \\ Makassar, Sulawesi Selatan, Indonesia Jalan Perintis Kemerdekaan KM 10 Makassar 90425 Indonesia \\ a mellyarti22@gmail.com \\ b zulkiflippi012@gmail.com
}

\begin{abstract}
Transportation problem, either in general or specifically in traffic, is a phenomenon occuring in human life. As the population of city increased, so does the traffic rate. If this is not followed by adequate improvement of transportation infrastructure, an imbalance might occur which will result in traffic jam. It can be seen particularly at Lingkar Tengah - Dr. Leimena road junction connecting Jalan Perintis Kemerdekaan Dr Leimena road due to driver/rider against the direction. Data analysis and planning using method of road capacity manual (MKJI 1997) and the traffic modelling using PTV Vissim. Based on road performance analysis it is known that DS (degree of saturation) is 0.12 with service level ' $A$ ' and average speed $\geq 23 \mathrm{~km} / \mathrm{h}$ with service level ' $D$ '. From the calculation result, modelling is conducted using PTV Vissim modelling. Alternative for handling the intersection is using $\mathbf{2}$ methods, which are traffic light signaling for 3 phases with immediate straight at west corner and immediate left turning at east corner and bridge closure on Dr. Leimena road. Using PTV Vissim, the result is that intensity of travel time increases about $47.68 \%$ and $57.40 \%$ on the intersection.
\end{abstract}

Keywords : simulation, intersection, performance, service level, speed time.

\footnotetext{
Abstrak- Masalah transportasi secara umum dan lalu lintas pada khususnya adalah merupakan fenomena yang terlihat sehari-hari dalam kehidupan manusia. Semakin tinggi tingkat populasi warga suatu kota, akan semakin tinggi juga tingkat perjalanannya. Jika peningkatan perjalanan ini tidak diikuti dengan peningkatan prasarana transportasi yang memadai, maka akan terjadi suatu ketidakseimbangan yang dapat menimbulkan kemacetan. Terkhusus pada simpang Jl. Lingkar Tengah - Jl. Dr. Leimena yang menghubungkan Jalan Perintis Kemerdekaan - Jl. Dr Leimena akibat pengendara yang melawan arah. Analisis data dan perencanaan menggunakan metode MKJI 1997 sebagai pedoman dan simulasi lalu lintasnya menggunakan software PTV Vissim. Hasil analisis data kinerja jalan diperoleh DS sebesar 0.12 dengan tingkat pelayanan A dan
}

kecepatan rata-rata $\geq 23 \mathrm{~km} / \mathrm{jam}$ dengan tingkat pelayanan $D$. Dari hasil perhitungan tersebut maka dilakukan rekayasa menggunakan simulasi PTV Vissim. Alternatif penanganan simpang menggunakan dua metode yaitu traffic light pemberian sinyal 3 fase dengan lurus langsung pada pendekat barat dan belok kiri langsung pada pendekat timur dan metode penutupan jembatan pada Jl. Dr. Leimena. Hasil simulasi dengan PTV Vissim diperoleh intensitas peningkatan waktu tempuh sebesar $\mathbf{4 7 . 6 8 \%}$ dan $57.40 \%$ pada simpang tersebut.

Kata kunci : Rekayasa, Simpang, Kinerja, Tingkat Pelayanan, Waktu Tempuh.

\section{Pendahuluan}

\section{A. Latar Belakang}

Masalah transportasi secara umum dan lalu lintas pada khususnya adalah merupakan fenomena yang terlihat sehari-hari dalam kehidupan manusia. Semakin tinggi tingkat populasi warga suatu kota, akan semakin tinggi juga tingkat perjalanannya. Jika peningkatan perjalanan ini tidak diikuti dengan peningkatan prasarana transportasi yang memadai, maka akan terjadi suatu ketidakseimbangan antara demand dan supply yang akhirnya akan menimbulkan suatu ketidak-lancaran dalam mobilitas yaitu berupa kemacetan.

Makassar merupakan salah satu Kota yang memiliki tingkat kepadatan penduduk yang tinggi. Berdasarkan Data Badan Pusat Statistik (BPS) Kota Makassar, tahun 2017 jumlah penduduk Kota Makassar berada diangka 1.489.011 jiwa. Angka tersebut mengalami penambahan sebesar 19.143 ditahun 2018 menjadi 1.508.154 jiwa. Sedang tahun 2019 angka ini kembali mengalami 
peningkatan yang cukup signifikan sebesar 18.523. Sehingga, jumlah penduduk di Kota Makassar hingga pada tahun 2019 mencapai 1.526.677 jiwa. Dari data tersebut sangat jelas terjadi pertumbuhan penduduk yang sangat pesat.

Terkhusus pada Pembangunan Middle Ring Road (MRR) atau Jalan lingkar tengah yang menghubungkan Jalan Perintis Kemerdekaan-Jalan Dr Leimena. Pembukaan jalan tersebut bertujuan agar dapat memudahkan pengendara yang berasal dari Jl. Perintis menuju Jalan Dr. Leimena ataupun sebaliknya. Namun dari pembukaan jalan tersebut masih dapat dikatakan kurang optimal sebab memicu adanya kemacetan pada simpang Jl. Lingkar Tengah - Jl. Dr. Leimena akibat pertemuan kendaraan yang ingin keluar/masuk di jalan tersebut serta tidak adanya alternative jalan bagi pengedara dari arah antang yang ingin melewati jalan lingkar tengah.

Hal tersebut menyebabkan masih adanya pengendaraa yang enggang melewati Jalan Lingkar Tengah Makassar dan/atau memicu terjadinya pelanggaran lalu lintas di Jl. Dr. Leimena. Sehingga hal inilah yang melatar belakangi penelitian ini dilakukan untuk mendapatkan solusi agar dapat mengoptimalkan kinerja dari Jalan Lingkar Tengah Makassar.

Berdasarkan hal tersebut, maka kami mengangkat judul "Rekayasa Lalu Lintas Pada Kawasan Simpang Jl. Lingkar Tengah - Jl. Dr. Leimena Di Kota Makassar".

Penelitian ini dimaksudkan untuk mengetahui :

1. Bagaimana kinerja Jalan Lingkar Tengah Makassar saat ini ?

2. Bagaiman rekayasa yang dapat dilakukan untuk Jl. Lingkar Tengah Makassar akibat Jl. Dr. Leimena?

3. Apa dampak setelah dilakukannya rekayasa lalu lintas bagi pengguna jalan?

Adapun tujuan dari dilakukannya penelitian ini :

1. Mengetahui kinerja lalu lintas yang terjadi pada Jalan Lingkar Tengah Makassar.

2. Mengetahui rekayasa lalu lintas yang dapat dilakukan untuk Jalan Lingkar Tengah akibat Jl. Dr. Leimena.

3. Mengetahui dampak setelah dilakukannya rekayasa lalu lintas bagi pengguna jalan.

\section{B. Tinjauan Pustaka}

1. Rekayasa lalu lintas adalah sesuatu penanganan yang berkaitan dengan perencanaan, perancangan geometrik dan operasi lalu lintas jalan raya serta jaringannya, terminal, penggunaan lahan serta keterkaitannya dengan mode transportasi lain. (Homburger \& Kell, 1981).

2. Volume Lalu Lintas

Volume lalu lintas adalah jumlah kendaraan yang melewati suatu titik pada segmen jalan dalam interval waktu tertentu. Secara matematis, volume lalu lintas dapat dihitung berdasarkan rumus berikut ini,

$$
Q=Q L V+Q H V \times \text { empHV + QMC x empMC }
$$

\section{Dimana:}

$\mathrm{Q}=$ Total volume lalu lintas ( $\mathrm{smp} / \mathrm{jam})$

QLV = Jumlah kendaraan ringan $(\mathrm{smp} / \mathrm{jam})$

$\mathrm{QHV}=$ Jumlah kendaraan berat (smp/jam)

empHV = Ekivalen kendaraan berat

QMC = Jumlah sepeda motor (smp/jam)

empMC $=$ Ekivalen sepeda motor

3. Kapasitas

Rumus mencari kapasitas yang sudah mempertimbangkan faktor hambatan (MKJI, 1997):

\section{C = Co $\times$ FCw $\times$ FCsp $\times$ FCsf $\times$ FCes (smp/jam)}

Dimana :

$\mathrm{C} \quad=$ Kapasitas (smp/jam)

$\mathrm{C}_{\mathrm{O}} \quad=$ Kapasitas dasar (smp/jam)

$\mathrm{FC}_{\mathrm{W}}=$ Faktor penyesuaian akibat lebar jalur lalu lintas.

$\mathrm{FC}_{\mathrm{SP}}=$ Faktor penyesuaian pemisah arah.

$\mathrm{FC}_{\mathrm{SF}} \quad=$ Faktor penyesuaian hambatan samping dan bahu jalan

$\mathrm{FC}_{\mathrm{CS}}=$ Faktor penyesuaian ukuran kota

4. Derajat Kejenuhan (DS)

DS didefinisikan sebagai rasio arus jalan terhadap kapasitas, yang digunakan sebagai factor utama dalam penentuan tingkat kinerja simpang dan segmen jalan. Nilai DS menunjukan apakah segmen jalan tersebut mempunyai masalah kapasitas atau tidak. Persamaan dasar untuk menentukan derajat kejenuhan adalah sebagai berikut:

Dimana:

$$
\mathbf{D S}=\mathbf{Q} / \mathbf{C}
$$

DS = Derajat kejenuhan

$\mathrm{Q}=$ Arus lalu lintas (smp/jam)

$\mathrm{C} \quad=$ Kapasitas $(\mathrm{smp} / \mathrm{jam})$ 
5. Tingkat Pelayanan

Tabel 1.1. Penggolongan Tingkat Pelayanan Jalan (Level of Services)

\begin{tabular}{|c|c|c|}
\hline $\begin{array}{c}\text { Tingkat } \\
\text { Pelayanan }\end{array}$ & Kondisi Arus Lalu Lintas & $\begin{array}{c}\text { Derajat } \\
\text { Kejenuhan (DS) }\end{array}$ \\
\hline A & $\begin{array}{c}\text { Bebas hambatan, volume lalu lintas rendah, } \\
\text { pengemudi dapat menjaga kecepatan tanpa } \\
\text { tundaan }\end{array}$ & $0,00-0,20$ \\
\hline B & $\begin{array}{c}\text { Arus stabil (untuk merancang jalan antar kota) } \\
\text { volume lalu lintas sesuai dengan rancangan } \\
\text { jalan. }\end{array}$ & $0,21-0,44$ \\
\hline C & $\begin{array}{c}\text { Arus stabil (untuk merancang jalan perkotaan), } \\
\text { umumnya pengemudi tidak bebas lagi memilih } \\
\text { lajur/menyalip. }\end{array}$ & $0,45-0,74$ \\
\hline D & $\begin{array}{c}\text { Arus mulai tidak stabil, kebebasan dan } \\
\text { kenyamanan pengemudi terbatas namun masih } \\
\text { wajar dalam waktu yang pendek, volume lalu } \\
\text { lintas masih dalam batas toleransi kapasitas } \\
\text { jalan. }\end{array}$ & $0,75-0,84$ \\
\hline E & $\begin{array}{c}\text { Arus tidak stabil, volume lalu lintas mulai jenuh, } \\
\text { terjadi tundaan dan antrian, laju kendaraan } \\
\text { kadang tersendat. }\end{array}$ & $0,85-1,00$ \\
\hline F & $\begin{array}{c}\text { Arus terhambat, macet, padat merayap sering } \\
\text { berhenti, antrian panjang, volume lalu lintas } \\
\text { turun drastis. }\end{array}$ & $>1,00$ \\
\hline
\end{tabular}

Sumber : MKJI 1997

Tabel 1.2. Indeks Tingkat Pelayanan Jalan Berdasarkan Kecepatan Rata-rata

\begin{tabular}{|c|c|c|c|}
\hline Kelas Arteri & I & II & III \\
\hline Kapasitas (km/jam) & $72-56$ & $56-48$ & $56-40$ \\
\hline ITP & \multicolumn{3}{|c|}{ Kecepatan } \\
\hline A & $\geq 56$ & $\geq 48$ & $\geq 40$ \\
\hline B & $\geq 45$ & $\geq 38$ & $\geq 31$ \\
\hline C & $\geq 35$ & $\geq 29$ & $\geq 21$ \\
\hline D & $\geq 28$ & $\geq 23$ & $\geq 15$ \\
\hline E & $\geq 21$ & $\geq 16$ & $\geq 11$ \\
\hline F & $<21$ & $<16$ & $<11$ \\
\hline
\end{tabular}

Sumber : Tamin \& Nahdalina (1998) dalam Muhtadi A (2010)

6. Perencanaan Waktu Sinyal Pada Simpang Penetuan waktu sinyal dapa diketahui dengan menghitun Waktu Antar Hijau dan Waktu Hilang dimana Waktu antar hijau atau inter green (IG) adalah periode kuning + merah semua antara dua fase sinyal yang berurutan.

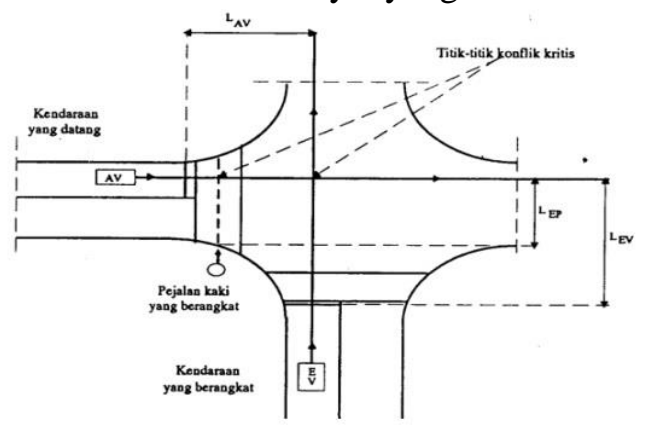

Gambar 2.1 Titik Konflik Kritis dan Jarak Untuk Keberangkatan dan Kedatangan Sumber : MKJI 1997
7. Vissim

Vissim adalah mikroskopis, waktu langkah, dan perilaku yang berbasis model simulasi untuk permodelan kota dan lalu lintas.

Konsepsi Kalibrasi dan Validitas Model Simulasi. Kalibrasi merupakan proses dalam membentuk nilai-nilai parameter yang sesuai sehingga model dapat mereplikasi lalu lintas hingga kondisi yang semirip mungkin dengan dilapangan. Proses kalibrasi dan validasi dilakukan berdasarkan jumlah volume arus lalu lintas dan panjang antrian (Putri, 2015).

Metode yang digunakan yaitu dengan rumus statistik Geoffrey E. Havers (GEH). Rumus GEH merupakan rumus yang menggabungkan perbedaan antara nilai relatif dan mutlak.

\section{Rumus GEH :}

$$
\text { GEH }=\frac{\sqrt{(\text { qsimulated-qobserved })^{2}}}{0,5 x \text { (qsimulated-qobserved })}
$$

Dimana :

$\mathrm{q}=$ Data volume arus lalu lintas (kendaraan/jam)

Tabel 1.3. Kesimpulan Hasil Perhitungan Rumus Statistik Geoffry E. Havers

\begin{tabular}{|l|l|}
\hline $\mathrm{GEH}<5,0$ & Diterima \\
\hline $5,0 \leq \mathrm{GEH} \leq 10,0$ & $\begin{array}{l}\text { Peringatan kemungkinan } \\
\text { model eror atau data } \\
\text { buruk }\end{array}$ \\
\hline $\mathrm{GEH}>10,0$ & Ditolak \\
\hline
\end{tabular}

Sumber : Putri, Nurjannah Haryanti, 2015.

\section{Metode Penelitian}

\section{A. Lokasi Penelitian dan Waktu Penelitian}

1) Lokasi Penelitian

Lokasi penelitian berada di Jl. Lingkar tengah Makassar - Jl. Dr. Leimena. Secara geografis berada pada koordinat $5^{\circ} 08^{\prime} 58,60^{\prime}$ LS dan $119^{\circ} 28^{\prime} 32,60^{\prime \prime}$ BT. Dengan jarak $\pm 9,6 \mathrm{~km}$ dari titik nol Kota Makassar. 


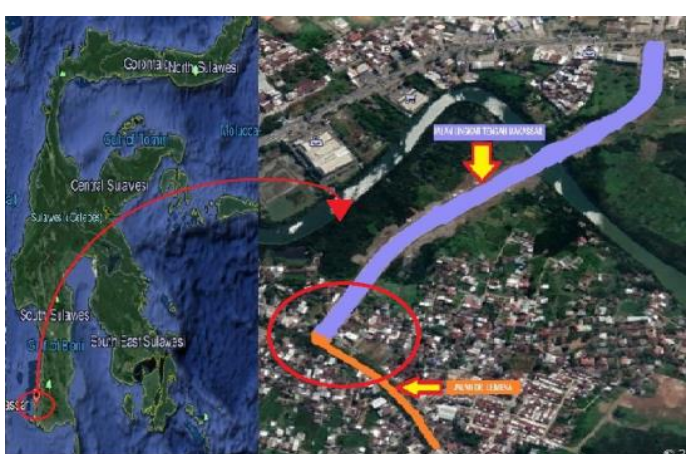

Gambar 2.1. Lokasi Penelitian

2) Waktu Penelitian

Adapun waktu penelitian selama 6 Bulan yang dimulai pada bulan Februari 2020 s/d bulan Juli 2020.

\section{B. Metode Analisis Data}

Metode yang digunakan dalam menganalisis data yang telah dikumpulkan untuk penelitian ini adalah sebagai berikut:

1) Menggunakan MKJI 1997

Data - data pada formulir yang telah diperoleh dari survei langsung dilapangan akan dihitung berdasarkan ketentuan MKJI 1997.

2) Menggunakan software PTV Vissim 9

Pada analisis menggunakan Vissim langkahlangkah pembuatan simulasi adalah sebagai berikut (Windarto, Pipit Candra, 2016) :

a) Input Background, masukkan gambar yang sudah diambil terlebih dahulu dari Google Earth.

b) Memuat jaringan jalan, membuat link dan connectors sesuai dengan kondisi jalan yang ada.

c) Menentukan jenis kendaraan, sesuaikan jenis kendaraan yang di survei dengan kendaraan yang akan dimasukkan ke dalam software VISSIM dan membuat 2D/3D Models untuk sepeda motor.

d) Mengisi vehicle types, menyesuaikan kategori yang sudah disediakan serta yang ditentukan sendiri. Pada menu ini terdapat parameter-parameter seperti kategori kendaraan, vehicle model, color, acceleration and deceleration, capacity, occupancy, dan lain-lain. e) Mengisi vehicle classes, mengklasifikasikan jenis kendaraan kedalam kategori kendaraan. Pada penelitian ini vehicle classes tetap dibagi menjadi 6 kelas kendaraan.

f) Input volume arus lalu lintas keseluruhan.

g) Membuat dan mengisi Signal Controllers, untuk mengatur Traffic Light pada jaringan jalan.

h) Simulation Continuous digunakan untuk memulai simulasi pada Vissim.

\section{Bagan Alir Penelitian}

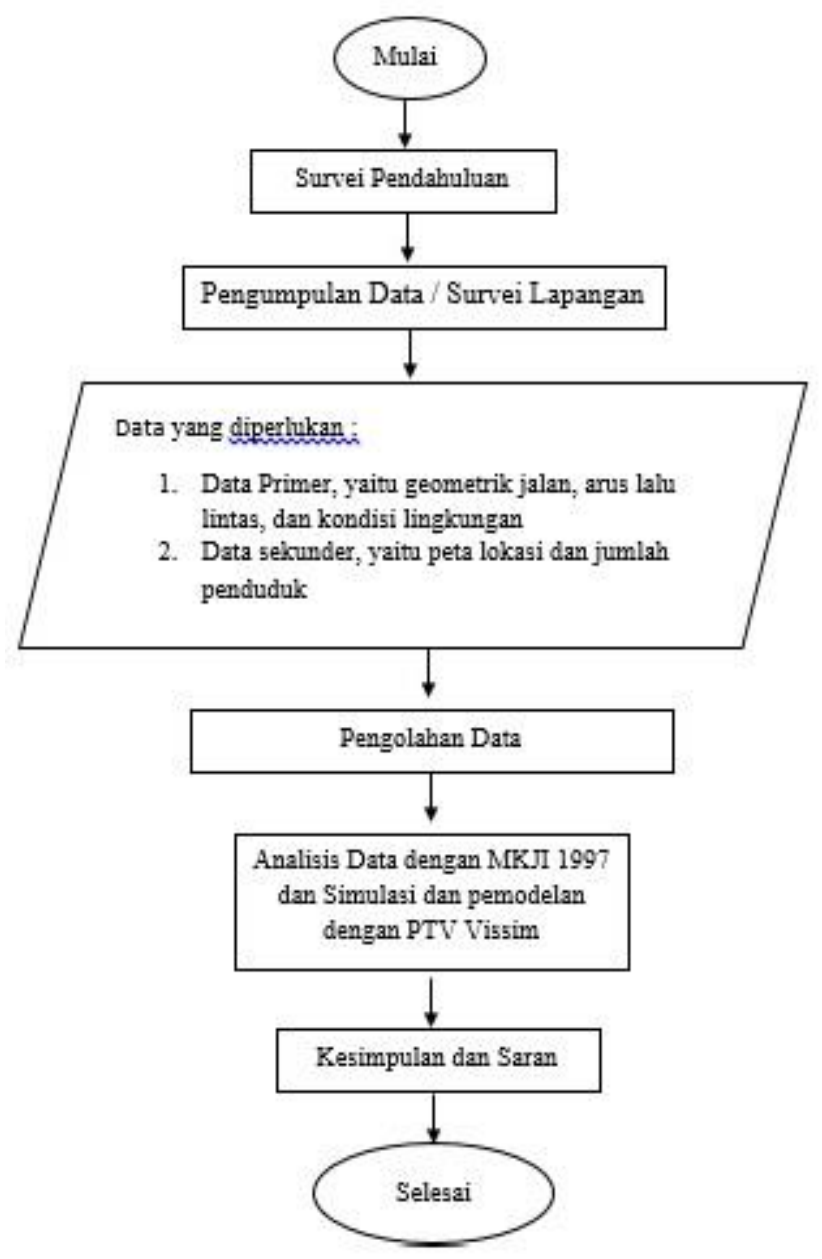

Gambar 2.2. Bagan Alir Penelitian

\section{Hasil dan Pembahasan}

\section{A. Hasil Pembahasan}

Indentifikasi hasil survei yang telah dilakukan dengan metode pengumpulan data primer dan 
sekunder. Data primer terdiri dari geometrik jalan, volume lalu lintas, kecepatan, panjang antrian serta fasilitas-fasilitas pendukung jalan lainnya. Adapun data sekunder berupa data jumlah penduduk.

\section{Survei Pendahuluan}

Survei ini dilakukan pada Jl. Lingkar Tengah Makassar - J1. Dr. Leimena pada hari Senin, 9 maret 2020 yang dilakukan pada pagi sampai sore hari pukul 06.00 - 18.00 Wita. Volume lalu lintas dihitung berdasarkan pengklasifikasian tipe kendaraan yang di bagi menjadi 3 golongan yaitu Sepeda Motor (MC), Kendaraan Ringan (LV), dan Kendaraan Berat (HV) dalam satuan kend/jam. Volume kendaraan yang dibagi sesuai tipe kendaraan per waktu penelitiannya.

2. Survei Geometrik

Survei geometrik yang dilakukan untuk mengetahui lebar jalan, bahu, median serta fasilitas-fasilitas jalan yang ada pada Jalan Lingkar Tengah Makassar dan Jalan Dr. Leimena yang dapat dilihat pada tabel 3.1, 3.2 dan 3.3.

Tabel 3.1. Data Geometrik Jalan Lingkar Tengah

\begin{tabular}{|c|c|c|}
\hline \multirow{2}{*}{ Tipe } & \multicolumn{2}{|c|}{ Ukuran (m) } \\
\cline { 2 - 3 } & Segmen 1 & Segmen 2 \\
\hline Lebar Jalan & 16,11 & 16,09 \\
\hline Median Jalan & \multicolumn{2}{|c|}{3} \\
\hline Kerb-Penghalang & 0,46 & 0,43 \\
\hline Jumlah Lajur & 4 & 4 \\
\hline Tipe Jalan & \multicolumn{2}{|c|}{$8 / 2$} \\
\hline
\end{tabular}

Sumber : Hasil Pengukuran dan Pengamatan di Lapangan

Tabel 3.2. Data Geometrik Jalan Dr. Leimena

\begin{tabular}{|l|l|}
\hline \multicolumn{1}{|c|}{ Tipe } & \multicolumn{1}{c|}{ Ukuran $(\mathrm{m})$} \\
\hline Lebar Jalan & 6,4 \\
\hline Lebar Bahu Jalan & 0,76 \\
\hline Jumlah Lajur & 2 \\
\hline Tipe Jalan & $2 / 1$ \\
\hline Konst. Jalan & Aspal \\
\hline Konst. Bahu & Tanah \\
\hline
\end{tabular}

Sumber : Hasil pengukuran dan Pengamatan di Lapangan
Tabel. 3.3. Data Geometrik Jembaran Jl. Dr. Leimena

\begin{tabular}{|l|l|}
\hline \multicolumn{1}{|c|}{ Tipe } & \multicolumn{1}{|c|}{ Ukuran $(\mathrm{m})$} \\
\hline Panjang Jembatan & 10,8 \\
\hline Lebar Jembatan & 7,5 \\
\hline Lebar Trotoar & 1 \\
\hline Panjang Trotoar & 10,8 \\
\hline Tinggi Trotoar & 0,21 \\
\hline \multicolumn{2}{|l|}{ Sumber : Hasil Pengukuran dan Pengamatan di Lapangan }
\end{tabular}

3. Survei Arus Lalu Lintas

a. Volume Lalu Lintas

Survei dilakukan selama 3 hari yaitu

Rabu, 17 Juni 2020, Jumat, 26 Juni 2020 dan

Senin, 6 Juli 2020 yang dilakukan pada jam-jam puncak. Pada survey pendahuluan dihasilkan yaitu periode Pagi (06.00 - 09.00), Siang (11.00 - 14.00) dan Sore (15.00 - 18.00) Wita, setelah itu dari data lapangan dilakukan pengolahan data dengan menjumlah dan merata-ratakan volume kendaraan dari 3 hari survei sebagai data masukan untuk pengolahan data.

Tabel 3.4. Volume Rata-rata Jumlah Kendaraan

\begin{tabular}{|c|c|c|c|c|}
\hline \multirow{2}{*}{ Lokasi } & \multirow{2}{*}{ Periode Waktu } & \multicolumn{3}{|c|}{ Volume Kendaraan (kend/jam) } \\
\cline { 2 - 5 } & & $\mathrm{MC}$ & $\mathrm{LV}$ & $\mathrm{HV}$ \\
\hline \multirow{3}{*}{ MRR (masuk) } & $06.00-09.00$ & 79 & 14 & 1 \\
\cline { 2 - 5 } & $11.00-14.00$ & 56 & 7 & 1 \\
\cline { 2 - 5 } & $15.00-18.00$ & 164 & 22 & 1 \\
\hline \multirow{3}{*}{ MRR (lawan arus) } & $06.00-09.00$ & 1430 & 149 & 5 \\
\cline { 2 - 5 } & $11.00-14.00$ & 467 & 70 & 12 \\
\cline { 2 - 5 } & $15.00-18.00$ & 506 & 47 & 1 \\
\hline \multirow{3}{*}{ MRR (keluar) } & $06.00-09.00$ & 529 & 122 & 22 \\
\cline { 2 - 5 } & $11.00-14.00$ & 508 & 217 & 33 \\
\cline { 2 - 5 } & $15.00-18.00$ & 1184 & 268 & 38 \\
\hline \multirow{3}{*}{ Leimena } & $06.00-09.00$ & 1219 & 243 & 20 \\
\cline { 2 - 5 } & $11.00-14.00$ & 1388 & 345 & 34 \\
\cline { 2 - 5 } & $15.00-18.00$ & 2954 & 676 & 37 \\
\hline
\end{tabular}

Sumber : Hasil Olahan Data Primer, 2020

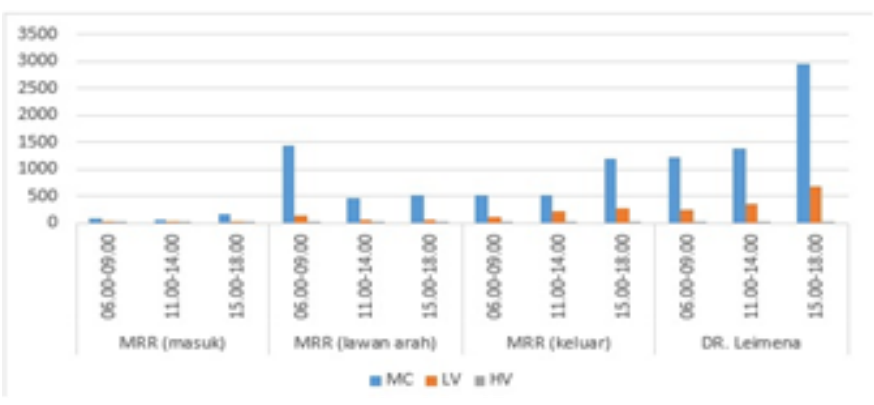

Gambar 3.1. Grafik Volume Rata-rata Jumlah Kendaraan 
Tabel 3.5. Volume Rata-rata Keseluruhan Kendaraan

\begin{tabular}{|c|c|c|c|c|c|}
\hline \multirow{2}{*}{ No. } & \multirow{2}{*}{ Pukul } & \multicolumn{4}{|c|}{ Volume Kendaraan Kend/Jam } \\
\cline { 3 - 6 } & & $\begin{array}{c}\text { MRR } \\
\text { (Lawan Arus) }\end{array}$ & $\begin{array}{c}\text { MRR } \\
\text { (masuk) }\end{array}$ & $\begin{array}{c}\text { MRR } \\
\text { (keluar) }\end{array}$ & Leimena \\
\hline 1 & $06.00-09.00$ & 1584 & 94 & 673 & 1482 \\
\hline 2 & $11.00-14.00$ & 548 & 65 & 759 & 1768 \\
\hline 3 & $15.00-18.00$ & 554 & 187 & 1493 & 3667 \\
\hline
\end{tabular}

Sumber : Hasil Olahan Data Primer, 2020

Dari tabel tersebut dapat diketahui bahwa volume kendaraan yang masuk ke arah jalan Lingkar Tengah didominasi oleh pengadara yang melawan arus dari Jl. Dr. Leimena terutama pada pagi hari. Pada arah keluar jalan Lingkar Tengah - Jl. Dr. Leimena dan Jl. Leimena terjadi peningkatan rata-rata jumlah kendaraan dari waktu ke waktu.

\section{b. Kecepatan Kendaraan}

Data kecepatan ini diambil secara bersamaan pada saat perhitungan volume kendaraan yakni selama 3 hari setiap interfal 15 menit, dengan jenis kendaraan masing-masing 5-10 sampel dengan jarak 20 meter sebagai batasan jarak pengamatan kendaraan. Pengambilan data kecepatan ini menggunakan stopwatch. Kecepatan lalu lintas dibagi berdasarkan jenis kendaraan yaitu :

a) Motorcycle (MC/ Sepeda Motor) yaitu semua jenis sepeda motor roda dua dan roda tiga

b) Light Vehicles (HV / Kendaraan Ringan) yaitu mobil penumpang, mobil pick up, sedan dan kendaraan ber as 2 dengan jarak antar as $2-3$ meter.

c) Heavy Vehicles (HV / Kendaraan Berat ) yaitu Bus, Truk 2 As, Truk 3 As dan kendaraan lebih dari 4 roda.

Setelah dari pengambilan data kecepatan kendaraan, diolah dan dicari rata-rata kecepatan kendaraan yang dinyatakan dalam satuan $\mathrm{km} / \mathrm{jam}$. Berikut merupakan hasil rata-rata kecepatan kendaraan pada saat dilakukan survey perhitungan volume kendaraan dapat dilihat pada Tabel 3.6.
Tabel 3.6. Rata-rata Kecepatan Kendaraan

\begin{tabular}{|l|l|c|c|}
\hline \multirow{2}{*}{ No. } & Nama Jalan & Waktu & Kecepatan Rata-rata $(\mathrm{km} / \mathrm{jam})$ \\
\hline \multirow{3}{*}{1} & \multirow{3}{*}{ MRR ( Lawan Arah) } & Pagi & 23,69 \\
\cline { 3 - 4 } & & Siang & 24,27 \\
\cline { 3 - 4 } & \multirow{3}{*}{2} & Sore & 20,77 \\
\hline \multirow{3}{*}{3} & \multirow{3}{*}{ MRR Keluar } & Pagi & 25,09 \\
\cline { 3 - 4 } & \multirow{3}{*}{ Leimena } & Siang & 24,00 \\
\cline { 3 - 4 } & & Sore & 20,33 \\
\hline & & Pagi & 27,21 \\
\cline { 3 - 4 } & Siang & 25,00 \\
\cline { 3 - 4 } & & Sore & 20,22 \\
\hline
\end{tabular}

Sumber : Hasil Olahan Data Primer, 2020

Dari tabel diatas menggambarkan kecepatan rata-rata kendaraan pada saat survei perhitungan volume lalu lintas yang disurvei berkisar antara 23-27 km/jam pada pagi hari, $24-25 \mathrm{~km} / \mathrm{jam}$ pada siang hari dan pada $20 \mathrm{~km} / \mathrm{jam}$ pada sore hari. Ada beberapa faktor yang mempengaruhi kecepatan kendaraan pada proses pengambilan data kecepatan yaitu, padatnya volume kendaraan yang melalui jalan tersebut, volume kendaraan yang tinggi jelas sangat berpengaruh terhadap kecepatan kendaraan serta perilaku pengemudi saat mengendarai kendaraan sangat berpengaruh terhadap kecepatan, misal adanya kendaraan yang tiba-tiba berhenti mendadak, sehingga mempengaruhi arus lalu lintas.

\section{c. Kecepatan Arus Bebas}

Pengambilan data kecepatan arus bebas dilakukan diatas pukul 22.00 WITA dengan menggunakan stopwatch. Dari data tersebut, dilakukan pengolahan data sehingga menghasilkan grafik distribusi kecepatan arus bebas kendaraan.

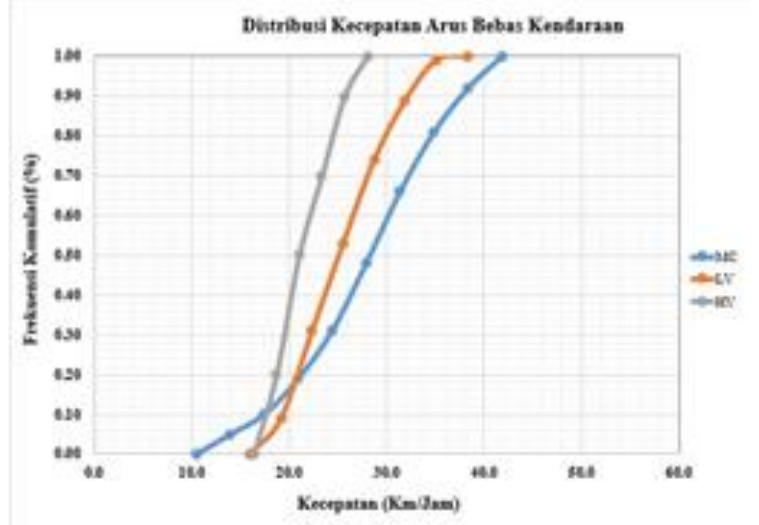

Gambar 3.2. (a) Distribusi Kecepatan di arah masuk Jalan Lingkar Tengah (Lawan Arah)

Sumber : Hasil Olahan Data Primer, 2020. 


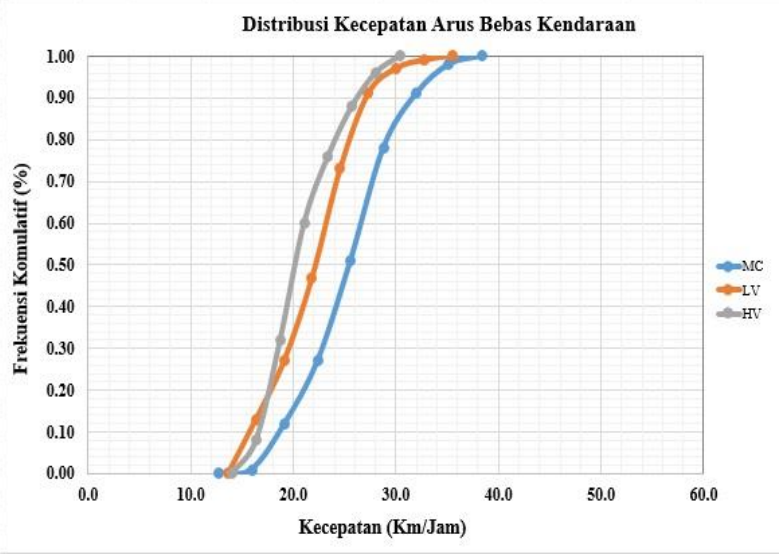

Gambar 3.2. (b) Distribusi Kecepatan di arah masuk Jalan Lingkar Tengah

Sumber : Hasil Olahan Data Primer, 2020.

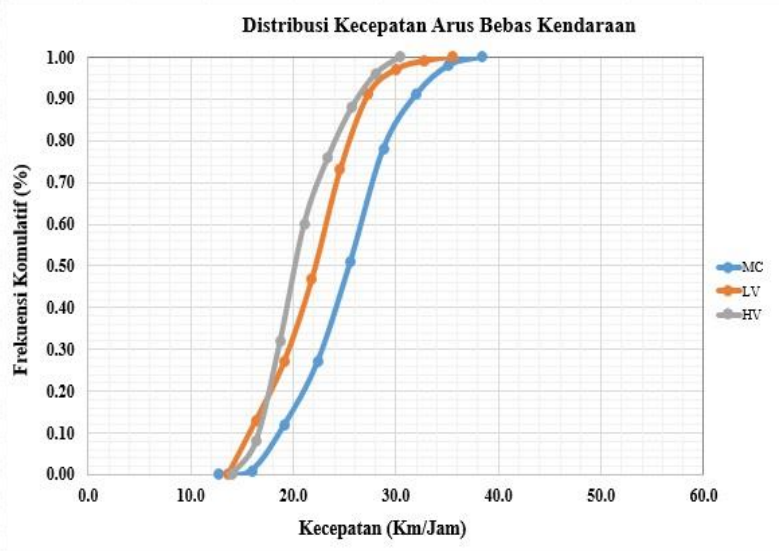

Gambar 3.2. (c) Distribusi Kecepatan di Ruas Jl. Dr. Leimena

Sumber : Hasil Olahan Data Primer, 2020.

Gambar 3.2 (a-c) menunjukkan bahwa frekuensi kecepatan kendaraan di Jl. Lingkar Tengah dan Jl. Dr. Leimena cenderung terdistribusi dengan normal untuk kondisi kepadatan jalan yang terjadi pada jalan tersebut. Dari ketiga grafik diatas juga menunjukkan bahwa frekuensi distribusi kecepatan untuk semua jenis kendaraan disetiap ruas hampir sama. Dimana dapat dilihat Gambar 3.2 (a) distribusi kecepatan kendaraan pada arah masuk Jalan Lingkar Tengah (lawan arah), sepeda motor (MC) memiliki kecepatan berkisar antara $13 \mathrm{~km} / \mathrm{jam}-41 \mathrm{~km} / \mathrm{jam}$. Kendaraan ringan (LV) memiliki kecepatan berkisar antara 18 $\mathrm{km} / \mathrm{jam}-36 \mathrm{~km} / \mathrm{jam}$ dan kendaraan berat (HV) memiliki kecepatan berkisar antara $17 \mathrm{~km} / \mathrm{jam}$ 27 km/jam. Gambar 3.2 (b) distribusi kecepatan kendaraan pada arah keluar Jalan Lingkar Tengah, sepeda motor (MC) memiliki kecepatan berkisar antara $14 \mathrm{~km} / \mathrm{jam}$ - 38 $\mathrm{km} / \mathrm{jam}$. Kendaraan ringan (LV) memiliki kecepatan berkisar antara $14 \mathrm{~km} / \mathrm{jam}$ - 34 $\mathrm{km} / \mathrm{jam}$ dan kendaraan berat (HV) memiliki kecepatan berkisar antara $16 \mathrm{~km} / \mathrm{jam}$ - 29 $\mathrm{km} / \mathrm{jam}$. Gambar 4.2 (c) distribusi kecepatan kendaraan kecepatan kendaraan pada ruas Jalan Dr. Leimena, sepeda motor (MC) memiliki kecepatan berkisar antara $14 \mathrm{~km} / \mathrm{jam}-33$ $\mathrm{km} / \mathrm{jam}$. Kendaraan ringan (LV) memiliki kecepatan berkisar antara $14 \mathrm{~km} / \mathrm{jam}$ - 32 $\mathrm{km} / \mathrm{jam}$ dan kendaraan berat (HV) memiliki kecepatan berkisar antara $16 \mathrm{~km} / \mathrm{jam}-22$ $\mathrm{km} / \mathrm{jam}$.

\section{d. Hambatan Samping}

Survei hambatan samping dilakukan dengan meninjau aktivitas-aktivitas yang terjadi pada jalan yang diamati. Hambatan samping yang diamati yaitu parkir di pinggir jalan, pejalan kaki, kendaraan lambat, dan kendaraan keluar masuk. Survei lalu lintas ini dilakukan bersamaan pada saat perhitungan volume. Hasil dari survei hambatan samping dapat dilihat pada tabel 4.8 dan gambar grafik hambatan samping.

Tabel 3.7. Hambatan Samping

\begin{tabular}{|c|c|c|c|}
\hline Lokasi & Pagi & Siang & Sore \\
\hline MRR Masuk & 39.2 & 14.3 & 30.7 \\
\hline MRR Keluar & 56.6 & 7.41 & 47.0 \\
\hline Leimena & 1135.6 & 499.0 & 486.2 \\
\hline
\end{tabular}

Sumber : Hasil Olahan Data Primer, 2020

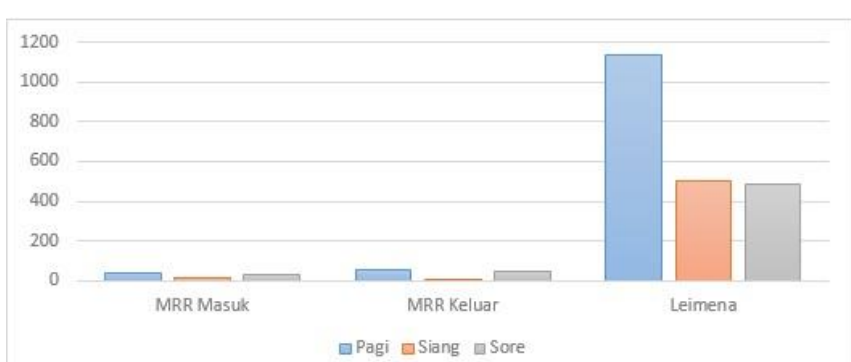

Gambar 3.3. Grafik Hambatan Samping

Dari tabel tersebut, diketahui bahwa hambatan samping pada Jl. Dr. Leimena termasuk dalam kelas sangat tinggi $(\mathrm{VH})$ pada pagi hari dan kelas sedang (M) pada siang dan sore. Pada Jl.Lingkar Tengah baik arah masuk ataupun keluar termasuk dalam kelas hambatan samping sangat rendah (VL). 
e. Panjang Antrian

Panjang antrian adalah nilai panjang antrian kendaraan yang berhenti sampai kendaraan tersebut kembali berjalan dengan satuan meter. Panjang antrian yang ditinjau terjadi pada simpang Jl. Lingkar Tengah - Jl. Dr. Leimena yang dilakukan dengan pengamatan langsung dilapangan (Juni 2020), menggunakan alat ukur meter. Berikut merupakan tabel panjang antrian rata-rata dari masing-masing ruas jalan.

Tabel 3.8. Panjang Rata-rata Antrian Puncak

\begin{tabular}{|c|c|c|c|}
\hline \multirow{2}{*}{ Nama Jalan } & \multicolumn{3}{|c|}{ Panjang Antrian } \\
\cline { 2 - 4 } & Pagi & Siang & Sore \\
\hline MRR (Lawan Arah) & 9 & 3 & 11 \\
\hline MRR Keluar & 0 & 7 & 16 \\
\hline Leimena & 3 & 7 & 24 \\
\hline
\end{tabular}

Sumber : Hasil Olahan Data Primer, 2020

Dari Tabel 3.8 menunjukkan bahwa panjang antrian rata-rata puncak terjadi pada periode sore dimana pada ruas Jl. Dr. Leimena memiliki nilai rata-rata panjang antrian dengan nilai $24 \mathrm{~m}$, untuk arah keluar Jl. Lingkar Tengah memiliki nilai panjang dengan nilai $16 \mathrm{~m}$, dan untuk panjang antrian yang melawan arah menuju Jl. Lingkar Tengah panjang antrian dengan nilai 11 meter.

\section{B. Pembahasan}

1. Kinerja Jalan Lingkar Tengah Makassar

\section{a. Kapasitas}

Kapasitas Jalan Lingkar Tengah Kota Makassar diperoleh melalui perkalian antara kapasitas dasar (Co) dengan beberapa faktor yang dibutuhkan menurut MKJI 1997 dimana nilai kapasitas (C) pada Jl. Lingkar Tengah Kota Makassar adalah sebagai berikut :

$$
\begin{aligned}
\mathrm{C} & =\mathrm{Co} \times \mathrm{FC}_{\mathrm{W}} \times \mathrm{FC}_{\mathrm{WB}} \times \mathrm{FC}_{\mathrm{SF}} \mathrm{FC}_{\mathrm{CS}} \\
& =(4 \times 1650) \times 1,08 \times 1,00 \times 0,93 \times 1,0 \\
& =6629 \mathrm{smp} / \mathrm{jam}
\end{aligned}
$$

Tabel 3.9. Kapasitas Jalan

\begin{tabular}{|l|l|l|l|l|l|l|l|}
\hline \multirow{2}{*}{ No. } & \multirow{2}{*}{ Lokasi } & \multirow{2}{*}{$\mathbf{C}_{\mathbf{o}}$} & \multicolumn{4}{|l|}{ Faktor Penyesuaian Kapasitas (F) } & \multirow{2}{*}{ Nilai C } \\
\cline { 4 - 8 } & & & $\mathbf{F C}_{\mathbf{W}}$ & $\mathbf{F C}_{\mathbf{S P}}$ & $\mathbf{F C}_{\mathbf{S F}}$ & $\mathbf{F C}_{\mathbf{C S}}$ & \\
\hline 1 & MRR Masuk & 6600 & 1.08 & 1.00 & 0.93 & 1.00 & 6629 \\
\hline 2 & MRR Keluar & 6600 & 1.08 & 1.00 & 0.93 & 1.00 & 6629 \\
\hline
\end{tabular}

Sumber : Hasil Perhitungan, 2020

\section{a. Derajat Kejenuhan}

Derajat kejenuhan dapat diperoleh dari hasil pembagian antara arus lalu lintas (Q) dengan kapasitas (C). Dengan mengetahui nilai derajat kejenuhan maka dapat ditentukan tingkat pelayanan dari jalan tersebut. Berikut adalah perhitungan derajat kejenuhan di arah keluar $\mathrm{Jl}$. Lingkar Tengah

\begin{tabular}{|c|c|c|c|c|c|c|}
\hline \multirow{2}{*}{ No. } & \multirow{2}{*}{ Lokasi } & \multirow{2}{*}{ Pukul } & $\mathrm{Q}$ & $\mathrm{C}$ & \multirow{2}{*}{ DS } & \multirow{2}{*}{ LoS } \\
\hline & & & (smp/jam) & (smp/jam) & & \\
\hline \multirow{3}{*}{1} & \multirow{3}{*}{$\begin{array}{l}\text { MRR } \\
\text { Masuk }\end{array}$} & $06.00-09.00$ & 775 & 6600 & 0.12 & A \\
\hline & & $11.00-14.00$ & 304 & 6600 & 0.05 & A \\
\hline & & $15.00-18.00$ & 339 & 6600 & 0.05 & A \\
\hline \multirow{3}{*}{2} & \multirow{3}{*}{$\begin{array}{l}\text { MRR } \\
\text { Keluar }\end{array}$} & $06.00-09.00$ & 362 & 6600 & 0.05 & A \\
\hline & & $11.00-14.00$ & 464 & 6600 & 0.07 & A \\
\hline & & $15.00-18.00$ & 795 & 6600 & 0.12 & A \\
\hline
\end{tabular}

$$
\begin{aligned}
D S & =\frac{Q}{C} \\
& =\frac{795}{6629} \\
& =0.12
\end{aligned}
$$

Tabel 3.10. Derajat Kejenuhan dan Tingkat Pelayanan

Sumber : Hasil Perhitungan, 2020

Dari hasil perhitungan pada tabel di atas, diperoleh nilai bahwa tingkat pelayanan pada Jalan Lingkar Tengah Kota Makassar yakni berada tingkat pelayan A pada setiap peride waktu.

Berdasarkan kecepatan rata-rata pada ruas jalan lingkar tengah kota makassar dapat dilihat pada tabel 3.11

Tabel 3.11. Kecepatan Rata-rata dan Tingkat Pelayanan

\begin{tabular}{|l|l|l|c|c|}
\hline \multirow{2}{*}{ No. } & \multirow{2}{*}{ Nama Jalan } & Waktu & $\begin{array}{c}\text { Kecepatan Rata-rata } \\
(\mathrm{km} / \mathrm{jam})\end{array}$ & Tingkat Pelayanan \\
\hline \multirow{3}{*}{1} & \multirow{3}{*}{ MRR Masuk } & Pagi & 23.69 & $\mathrm{D}$ \\
\cline { 3 - 5 } & & Siang & 24.27 & $\mathrm{D}$ \\
\cline { 3 - 5 } & Sore & 20.77 & $\mathrm{E}$ \\
\hline \multirow{2}{*}{2} & \multirow{3}{*}{ MRR Keluar } & Pagi & 25.09 & $\mathrm{D}$ \\
\cline { 3 - 5 } & & Siang & 24.00 & $\mathrm{D}$ \\
\cline { 3 - 5 } & & Sore & 20.33 & $\mathrm{E}$ \\
\hline
\end{tabular}

Sumber : Hasil Perhitungan, 2020

Dari tabel 3.11, tingkat pelayanan pada Jl. Lingkar Tengah berdasarkan indeks Pelayanan Kecepatan Rata-rata, diperoleh nilai D pada pagi dan siang serta nilai $E$ pada sore hari. 
2. Pemodelan Lalu Lintas Menggunakan Vissim sebelum Rekayasa

Pemodelan rekayasan ini menggunakan perangkat lunak PTV VISSIM 9. Model simulasi lalu lintas dilakukan sebelum dan sesudah di rekayasa dibangun dengan membentuk parameter model (kalibrasi) terlebih dahulu dengan membandingkan hasil model simulasi dengan hasil survei di lapangan.

\section{a. Kalibrasi Model Mikro-S}

Tujuan dari proses kalibrasi adalah memperoleh hasil analisis (output) yang sesuai dengan realita di lapangan (hasil observasi) dengan mengubah dan membentuk parameterparameter yang ada pada Vissim dengan metode trial and error dan hasil analisis uji GEH (Geoffrey E. Havers).

\begin{tabular}{|l|l|l|l|l|l|}
\multirow{2}{*}{ No } & Parameter & Sebelum & \multicolumn{3}{|c|}{ Sesudah } \\
\cline { 4 - 6 } & Observed vehicles in front & 4 & 3 & 3 & 2 \\
\hline 2 & $\begin{array}{l}\text { Standstill distance (in front of } \\
\text { obstacles) is fox }\end{array}$ & - & $\checkmark$ & $\checkmark$ & $\checkmark$ \\
\hline 3 & $\begin{array}{l}\text { Standstill distance in front of } \\
\text { static obstacles }\end{array}$ & 0,5 & 0,5 & 0,5 & 0,08 \\
\hline 4 & $\begin{array}{l}\text { W74ax: Average standstill } \\
\text { distance }\end{array}$ & 2,00 & 0,2 & 1,0 & 0,08 \\
\hline 5 & $\begin{array}{l}\text { W74bxAdd: Additive factor } \\
\text { for security distance }\end{array}$ & 2,00 & 0,2 & 0,5 & 0,10 \\
\hline 6 & $\begin{array}{l}\text { W74bxMult: Multiplicative } \\
\text { factor for security distance }\end{array}$ & 3,00 & 0,2 & 0.77 & 0,10 \\
\hline 7 & Advanced merging & - & $\checkmark$ & $\checkmark$ & $\checkmark$ \\
\hline 8 & Desired lateral position & Middle of lane & Any & Any & Any \\
\hline 9 & Overtake left (default) & - & $\checkmark$ & $\checkmark$ & $\checkmark$ \\
\hline 10 & Overtake right (default) & - & $\checkmark$ & $\checkmark$ & $\checkmark$ \\
\hline 11 & $\begin{array}{l}\text { Lateral minimum distance at } \\
50 \text { km/h }\end{array}$ & 1,00 & 0,10 & 1,00 & 0,02 \\
\hline 12 & $\begin{array}{l}\text { Lateral minimum distance at } \\
\text { 0 km/h }\end{array}$ & 0,20 & 0,1 & 0,2 & 0,02 \\
\hline 13 & Minimum headway & 0,50 & 0,3 & 0,5 & 0,07 \\
\hline
\end{tabular}

Sumber : Hasil Trial dan Error
Tabel 3.13. Hasil Kalibrasi dengan Uji Geoffrey E.

\begin{tabular}{|c|c|c|c|c|c|c|c|}
\hline No & Waktu & $\begin{array}{l}\text { Nama } \\
\text { Jalan }\end{array}$ & $\begin{array}{l}\mathrm{Q} \\
\text { Observasi }\end{array}$ & $\frac{\mathrm{Q}}{6} \frac{\text { Observasi }}{6}$ & $\begin{array}{l}\mathrm{Q} \\
\text { Simulasi }\end{array}$ & $\begin{array}{l}\text { Nilai } \\
\text { GEH }\end{array}$ & Ket. \\
\hline \multirow{3}{*}{1} & \multirow{3}{*}{ PAGI } & Leimena & 791 & 132 & 141 & 0,78 & Diterima \\
\hline & & $\begin{array}{l}\text { MRR } \\
\text { Keluar }\end{array}$ & 705 & 118 & 111 & 0,61 & Diterima \\
\hline & & $\begin{array}{l}\text { MRR } \\
\text { Masuk }\end{array}$ & 1540 & 257 & 246 & 0,67 & Diterima \\
\hline \multirow{3}{*}{2} & \multirow{3}{*}{ SIANG } & Leimena & 1004 & 167 & 179 & 0,89 & Diterima \\
\hline & & $\begin{array}{l}\text { MRR } \\
\text { Keluar }\end{array}$ & 891 & 149 & 140 & 0,71 & Diterima \\
\hline & & $\begin{array}{l}\text { MRR } \\
\text { Masuk }\end{array}$ & 576 & 96 & 93 & 0,31 & Diterima \\
\hline \multirow{3}{*}{3} & \multirow{3}{*}{ SORE } & Leimena & 1986 & 331 & 343 & 0,65 & Diterima \\
\hline & & $\begin{array}{l}\text { MRR } \\
\text { Keluar }\end{array}$ & 1885 & 314 & 307 & 0,41 & Diterima \\
\hline & & $\begin{array}{l}\text { MRR } \\
\text { Masuk }\end{array}$ & 583 & 97 & 95 & 0,22 & Diterima \\
\hline
\end{tabular}

Sumber : Hasil Perhitungan, 2020

Dari Tabel 3.13 menunjukkan bahwa nilai Q merupakan volume kendaraan dan seperti pada tabel di atas nilai $Q$ observasi dibagi dengan angka 6 dikarenakan pada saat proses simulasi dijalankan lama waktu yang bisa disimulasikan hanya 600 detik, hal ini merupakan keterbatasan dari versi VISSIM yang digunakan. Namun, setelah dikalibrasi dengan menggunakan uji GEH untuk semua ruas jalan dimasing-masing periode sudah memenuhi syarat, dimana nilai yang diperoleh $<5$ yang berarti model simulasi sudah dapat diterima atau sudah terkalibrasi.

b. Validasi Hasil Kolaborasi Model MikroSimulasi

Acuan validasi ini yaitu panjang antrian kendaraan dimana kita membandingkan panjang antrian pada model simulasi dengan hasil observasi dilapangan. Analisis yang digunakan adalah dengan Uji Chi-square

Tabel 3.14. Hasil Validasi dengan uji Chi-Square

\begin{tabular}{|l|l|l|l|l|}
\hline \multirow{2}{*}{ Hasil } & \multirow{2}{*}{ Nama Jalan } & \multicolumn{3}{|l|}{ Panjang Antrian } \\
\cline { 3 - 5 } & & Pagi & Siang & Sore \\
\hline \multirow{3}{*}{ Observasi } & Leimena & 3 & 7 & 24 \\
\cline { 2 - 5 } & MRR Keluar & 0 & 3 & 11 \\
\cline { 2 - 5 } & Lawan Arah & 9 & 7 & 16 \\
\hline \multirow{3}{*}{ Simulasi } & Leimena & 3 & 3 & 21 \\
\cline { 2 - 5 } & MRR Keluar & 1 & 3 & 10 \\
\cline { 2 - 5 } & Lawan Arah & 10 & 9 & 12 \\
\hline Chi-square Hitung & 7,671 & \\
\hline \multicolumn{4}{|l|}{ Chi-square Tabel } & 9,487 \\
\hline Kesimpulan & Diterima & \\
\end{tabular}

Sumber : Hasil Perhitungan, 2020 


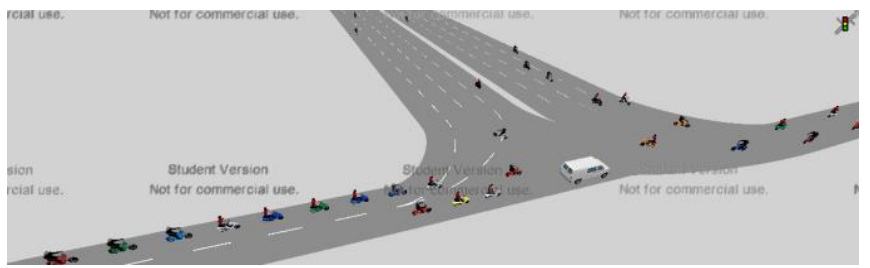

Gambar 3.4. (a) Sebelum Kalibrasi

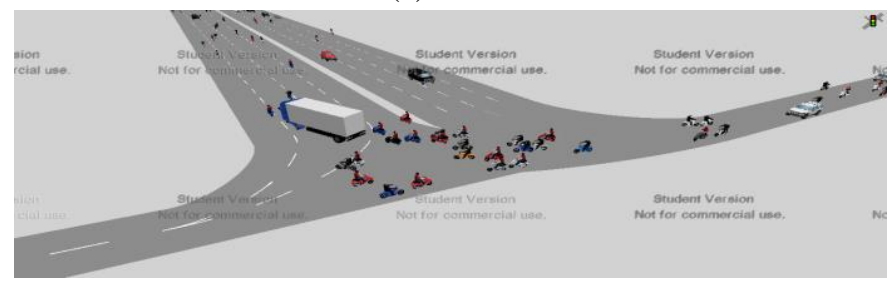

Gambar 3.4. (b) Setelah Kalibrasi

3. Perencanaan Pemodelan Rekayasa Lalu Lintas

Perencanaan Pemodelan Rekayasa Lalu Lintas dengan Vissim menggunakan dua metode alternatif yaitu dengan melakukan penutupan jembatan atau dengan pemasangan traffic light pada simpang.

a. Rekayasa Lalu Lintas dengan Metode Penutupan Jembatan

Rekayasa Lalu Lintas dengan melakukan Penutupan Jembatan di Jl. Dr. Leimena agar mengurangi tingkat pengendara yang melawan arah menuju simpang. Rekayasa dilakukan dengan melakukan pemodelan menggunakan Vissim untuk membandingkan sebelum dan setelah dilakukannya rekayasa.

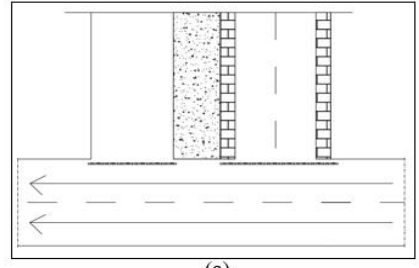

(a)

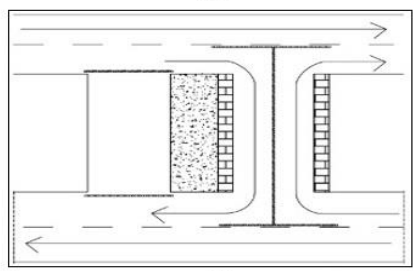

(c)

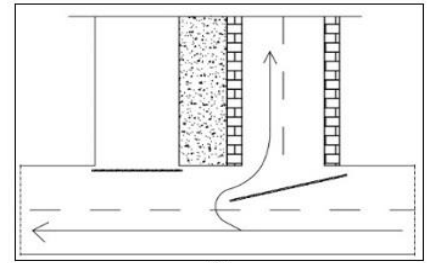

(b)

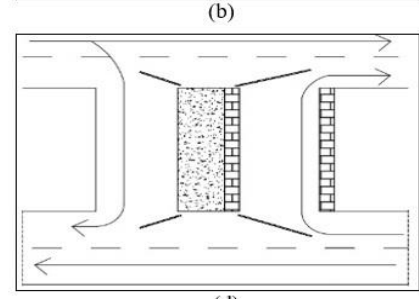

(d)

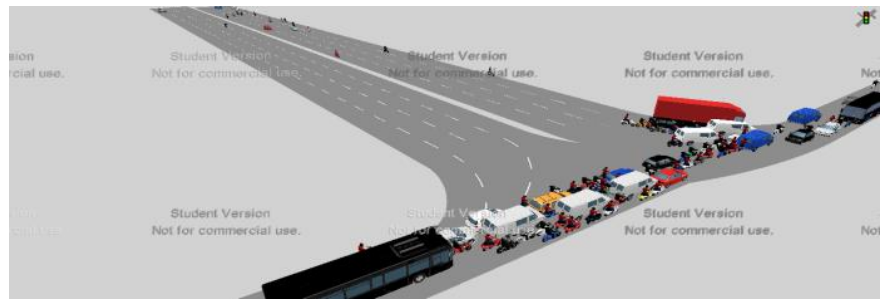

Gambar 3.6. (a) Sebelum Rekayasa Penutupan Jembatan

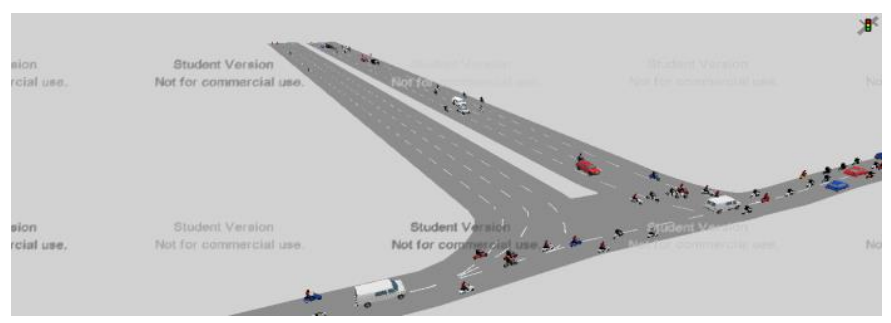

Gambar 3.6. (b) Setelah Rekayasa Penutupan Jembatan

b. Rekayasa Lalu Lintas dengan Perencanaan Traffic Light

Rekayasa Lalu Lintas dengan perencanaan Traffic Light pada simpang Jl. Lingkar- Tengah - J1. Dr. Leimena agar kemacetan pada simpang dapat terurai. Penentuan waktu siklus dilakukan dengan metode perhitungan berdasarkan MKJI 1997. Alternative yang dilakukan dengan Pemberian sinyal 3 fase, lurus langsung pada pendekat Barat dan belok kiri langsung pada pendekat Timur. Hasil dari perhitungan tersebut kemudian dibawah ke Vissim untuk melihat kondisi dari hasil rekayasa tersebut.

Tabel 3.15 (a) Formulir SIG-I (lurus langsung pendekat Barat dan LTOR pendekat Timur)

\begin{tabular}{|c|c|c|c|c|c|c|c|c|c|c|}
\hline & & \multirow[b]{3}{*}{$\begin{array}{c}\text { Hambatan } \\
\text { Samping } \\
\text { TR }\end{array}$} & \multirow[b]{3}{*}{\begin{tabular}{|l} 
Median \\
YaIdk
\end{tabular}} & \multirow[b]{3}{*}{$\begin{array}{c}\text { Kelandaian } \\
++\%\end{array}$} & \multirow{4}{*}{$\begin{array}{c}\text { Belok } \\
\text { Kiri } \\
\text { Langsun } \\
\mathrm{g} \text { gaTduk } \\
(6)\end{array}$} & \multirow{4}{*}{$\begin{array}{c}\text { Jarak Ke } \\
\text { Kendaraan } \\
\text { Parkir (m) } \\
(7)\end{array}$} & & & & \\
\hline \multirow[b]{2}{*}{$\begin{array}{c}\text { Kode } \\
\text { Pendekat }\end{array}$} & \multirow[b]{2}{*}{$\begin{array}{c}\text { Tipe } \\
\text { Linghungan } \\
\text { Jalan }\end{array}$} & & & & & & \multicolumn{4}{|c|}{ Lebar Pendekat (m) } \\
\hline & & & & & & & $\begin{array}{c}\text { Pendekat } \\
W_{A}\end{array}$ & $\begin{array}{c}\text { Masulk } \\
\text { WMastK }\end{array}$ & $\begin{array}{c}\text { Belok Kiri } \\
\text { Langsung } \\
\text { WLror }\end{array}$ & $\begin{array}{r}\text { Kelluar } \\
\text { Wretua }\end{array}$ \\
\hline (1) & $(2)$ & (3) & (4) & (5) & & & $(8)$ & (9) & $(10)$ & (11) \\
\hline $\mathrm{B}(\mathrm{ST})$ & $\mathrm{COM}$ & Rendah & Tidak & - & Tidak & . & 3.2 & 3.2 & - & 3.2 \\
\hline $\mathrm{B}(\mathrm{RT})$ & $\mathrm{COM}$ & Rendah & Tidak & - & Tidak & - & 3.2 & 3.2 & - & 16.09 \\
\hline $\mathrm{T}(\mathrm{ST})$ & $\mathrm{COM}$ & Rendah & Tidak & - & Tidak & - & 3.2 & 3.2 & . & 3.2 \\
\hline $\mathrm{T}(\mathrm{LT})$ & $\mathrm{COM}$ & Rendah & Ya & - & Ya & - & 3.2 & 2 & 1.2 & 16.09 \\
\hline $\mathrm{S}(\mathrm{RT})$ & $\mathrm{COM}$ & Rendah & Tidak & - & Tidak & - & 16.11 & 16.09 & - & 3.2 \\
\hline $\mathrm{S}(\mathrm{LI})$ & $\mathrm{COM}$ & Rendah & Tidak & - & Tidak & - & 16.11 & 16.09 & - & 3.2 \\
\hline
\end{tabular}

Sumber : Hasil Perhitungan, 2020

Gambar 3.5. Alternatif Penutupan Jembatan 
Tabel 3.16 (b) Formulir SIG-II (3 Fase dengan lurus langsung pada pendekat Barat dan belok kiri langsung pada pendekat Timur)

\begin{tabular}{|c|c|c|c|c|c|c|c|c|c|c|c|c|c|c|c|c|c|}
\hline \multirow{5}{*}{$\begin{array}{c}\text { Koded } \\
\text { Pendeleat }\end{array}$} & & & & & \multicolumn{11}{|c|}{ ARUS LALULINTAS BER } & \multicolumn{2}{|c|}{ KENDTAKBERMOTOR } \\
\hline & \multirow{4}{*}{ Arath } & \multirow{2}{*}{\multicolumn{3}{|c|}{ 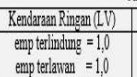 }} & \multirow{2}{*}{\multicolumn{3}{|c|}{$\begin{array}{l}\text { Kendaran Berat }(\mathrm{HV}) \\
\text { emp telindumg }=1,3 \\
\text { emp terlanan }=1,3\end{array}$}} & \multirow{2}{*}{\multicolumn{3}{|c|}{ 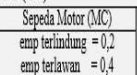 }} & \multirow{2}{*}{\multicolumn{3}{|c|}{$\begin{array}{c}\text { Rerdaranan Total WV } \\
\text { Bemotor }\end{array}$}} & \multirow{2}{*}{\multicolumn{2}{|c|}{ Rasio Berbelok }} & & \multirow{4}{*}{$\begin{array}{l}\text { Rasio PONM }= \\
\text { UNMNV }\end{array}$} \\
\hline & & & & & & & & & & & & & & & & UM & \\
\hline & & \multirow[t]{2}{*}{ kend } & \multicolumn{2}{|c|}{ smjjem } & \multirow{2}{*}{\begin{tabular}{|c|} 
kend \\
$\mathrm{jmm}$
\end{tabular}} & \multicolumn{2}{|c|}{ smojem } & \multirow{2}{*}{$\begin{array}{c}\text { kend } \\
\text { jum }\end{array}$} & \multicolumn{2}{|c|}{$\operatorname{smpjem}$} & \multirow{2}{*}{\begin{tabular}{l|l} 
kend & \\
&
\end{tabular}} & \multicolumn{2}{|c|}{ smpjiam } & & \multirow{2}{*}{ an kendja } & \\
\hline & & & Telintuge & Taknaw & & Tolinumg & Tolaknan & & Tolihnug & Telarian & & Tơlinimg & 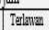 & $P_{\text {IT }}$ & & & \\
\hline (l) & (2) & (3) & (4) & (5) & $(6)$ & (7) & (8) & (9) & $(10)^{\circ}$ & (11) & (112) & (13) & (14) & \begin{tabular}{|l|} 
\\
\end{tabular} & (16) & (17) & (18) \\
\hline & LT & $\frac{11}{0}$ & $\frac{7}{0}$ & 17 & 0 & 0 & $\frac{0}{0}$ & 0 & 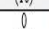 & $\frac{1+1}{0}$ & $\frac{14}{0}$ & 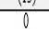 & $\frac{1+4}{0}$ & & & $\frac{1+1}{0}$ & \\
\hline & ST & 1 & 1 & 1 & 0 & 0 & 0 & 18 & 3.6 & 7.2 & 19 & $\therefore$ & 8 & & & 0 & \\
\hline B & R.T & 138 & 138 & 138 & 4 & 5.2 & 5.2 & 1398 & 29.6 & 5592 & 1540 & 423 & 102 & & 0.99 & 3 & 0.0019 \\
\hline & Total & 139 & 139 & 139 & 4 & 5.2 & 5.2 & 1416 & 283.2 & 3664 & $\mid \begin{array}{l}1270 \\
1159\end{array}$ & 427.4 & 710.6 & & & 3 & \\
\hline & IT & 25 & 25 & 25 & 1 & 1.3 & 1.3 & 164 & 32.8 & 65.6 & 190 & 59 & 92 & 0.09 & & 9 & \\
\hline T & ST & 329 & 329 & 329 & 10 & 13 & 13 & 1456 & 291.2 & 5824 & 1995 & 633 & 924 & & & 9 & 0001 \\
\hline & $\mathrm{BT}$ & 0 & 0 & 0 & 0 & 0 & 0 & 0 & 0 & 0 & 0 & 0 & 0 & & & 0 & \\
\hline & Total & 354 & 354 & 354 & I1 & 14.3 & 143 & 1620 & 324 & 648 & 1985 & 692.3 & 10163 & & & 18 & \\
\hline & \begin{tabular}{|l|} 
LT \\
\end{tabular} & \begin{tabular}{|l|}
347 \\
\end{tabular} & 347 & 347 & \begin{tabular}{|l|}
38 \\
\end{tabular} & 49.4 & 49.4 & 1500 & 300 & 600 & \begin{tabular}{|l|}
1889 \\
\end{tabular} & 696 & 996 & 1.00 & & 14 & \\
\hline & ST & 0 & 0 & 0 & 0 & 0 & 0 & 0 & 0 & 0 & 0 & $y$ & 0 & & & 0 & 0007 \\
\hline$\delta$ & RT & 0 & 0 & 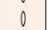 & 0 & 0 & 0 & 8 & 1.6 & 3.2 & 8 & 2 & 3 & & 0.0032 & 0 & 0.0014 \\
\hline & Total & 347 & 347 & 347 & 38 & 49.4 & 494 & 1508 & 3016 & 6032 & 1893 & 698 & 9996 & & & 14 & \\
\hline
\end{tabular}

Sumber : Hasil Perhitungan, 2020

Tabel 3.16 (c) Formulir SIG-III (3 Fase dengan lurus langsung pada pendekat Barat dan belok kiri langsung pada pendekat Timur)

\begin{tabular}{|c|c|c|c|c|c|c|}
\hline \multicolumn{2}{|c|}{$\begin{array}{l}\text { LALULNTAS } \\
\text { BERAIGKAT }\end{array}$} & \multicolumn{4}{|c|}{ LALULNTASDATANG } & \multirow[t]{2}{*}{ Waltu Nerah Sema (det } \\
\hline Pandete & Reepeptan & \begin{tabular}{|l} 
Penderat \\
\end{tabular} & $B$ & I & $s$ & \\
\hline & VEmidet & Revegatan VIA didet & 10 & 10 & 10 & \\
\hline \multirow{2}{*}{ B } & \multirow{2}{*}{10} & Jarab beraglatat- datang (m) & & & $189+5 \cdot 21.7$ & \\
\hline & & 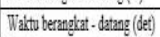 & & & $1.89+0.5 \cdot 2.17$ & 0.22 \\
\hline \multirow[b]{2}{*}{ I } & \multirow{2}{*}{10} & Jararb beraglatat-datang (m) & & & $21.7+5 \cdot 24.7$ & \\
\hline & & 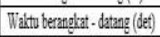 & & & $2.17+05 \cdot 2.47$ & 0.20 \\
\hline \multirow{8}{*}{ s } & \multirow{3}{*}{10} & Jarab beraglat. datang (m) & $21.7+5 \cdot 189$ & $247+5 \cdot 249$ & & \\
\hline & & 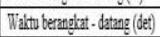 & $2.17+0.5 \cdot 1.89$ & $2.77+0.5 \cdot 2.49$ & & 1.26 \\
\hline & & \multicolumn{4}{|l|}{ 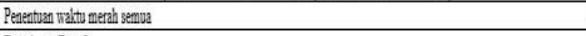 } & \\
\hline & \multirow{5}{*}{ 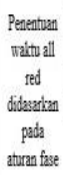 } & \multirow{2}{*}{\multicolumn{4}{|c|}{ Fase $1 \rightarrow$ Fase 2}} & 2 \\
\hline & & & & & & 2 \\
\hline & & \multicolumn{4}{|l|}{ Fase $3 \rightarrow \rightarrow$ Fase 1} & 2 \\
\hline & & Jomalah Fuse & 3 & Runinglase & 3 & 9 \\
\hline & & \multicolumn{4}{|c|}{ 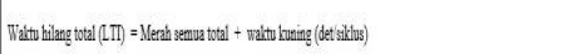 } & 15 \\
\hline
\end{tabular}

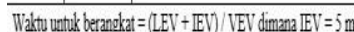

Whaturuatuld datang =LAV/ VAV

\section{Sumber : Hasil Perhitungan, 2020}

Tabel 3.16 (d) Formulir SIG-IV (3 Fase dengan lurus langsung pada pendekat Barat dan belok kiri langsung pada pendekat Timur)

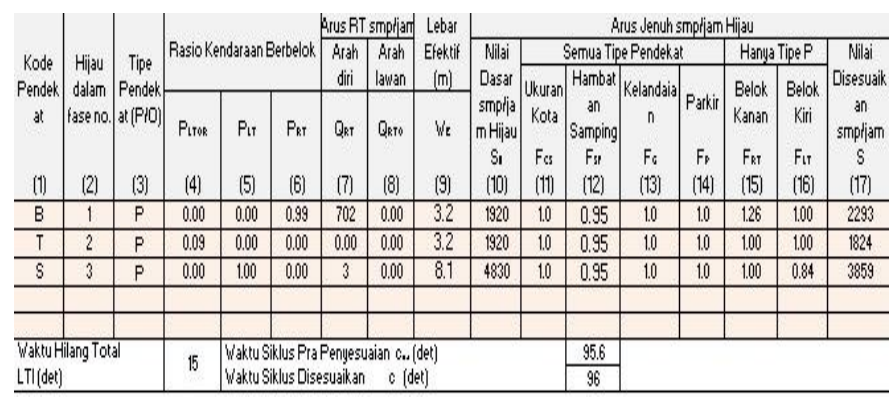

Sumber : Hasil Perhitungan, 2020
Tabel 3.16 (e) Formulir SIG-IV (3 Fase dengan lurus langsung pada pendekat Barat dan belok kiri langsung pada pendekat Timur)

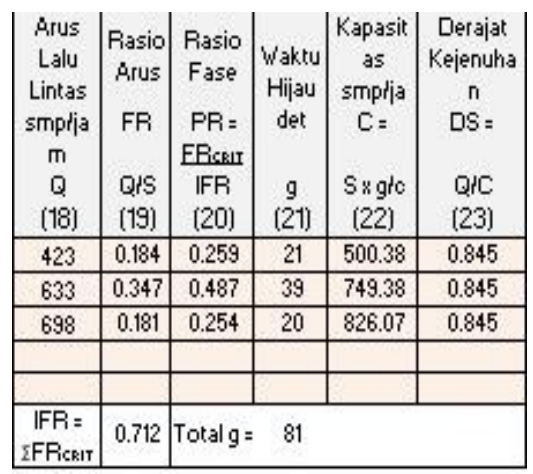

Sumber : Hasil Perhitungan, 2020

Tabel 3.16 (f) Formulir SIG-V (3 Fase dengan lurus langsung pada pendekat Barat dan belok kiri langsung pada pendekat Timur)

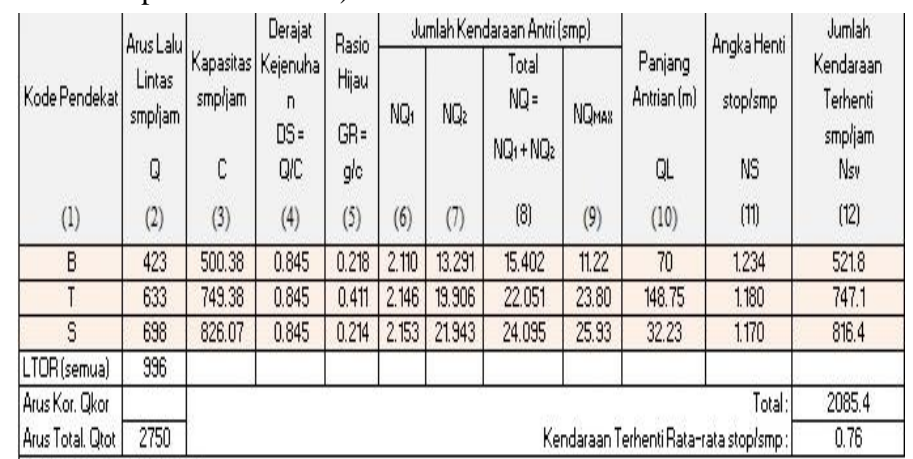

\section{Aruskor = Arus yang dikoreksi}

Sumber : Hasil Perhitungan, 2020

Tabel 3.16 (g) Formulir SIG-V (3 Fase dengan lurus langsung pada pendekat Barat dan belok kiri langsung pada pendekat Timur)

\begin{tabular}{|c|c|c|c|}
\hline \multicolumn{4}{|c|}{ Tundaan } \\
\hline TundaanLalu & Tundaan Geometri & Tundaan Rata-rata & Tundaan Total \\
\hline $\begin{array}{l}\text { Lintas Rata- } \\
\text { detlsmp }\end{array}$ & $\begin{array}{l}\text { Rata-rata } \\
\text { detlsmp }\end{array}$ & $\begin{array}{c}\text { dellsmp } \\
D=\end{array}$ & smp.det \\
\hline DT & $D G$ & $D T+D G$ & DNQ \\
\hline (13) & (14) & (15) & (16) \\
\hline 59.42 & 4.00 & 63.42 & 26813.34 \\
\hline 43.65 & 4.00 & 47.65 & 30169.36 \\
\hline 53.85 & 4.00 & 57.85 & 40382.59 \\
\hline & & Tota & 97365.29 \\
\hline & Tundaan Simpang & ta-rata stopismp: & 35.40 \\
\hline
\end{tabular}

Sumber : Hasil Perhitungan, 2020

Berdasarkan tabel rekapitulasi diatas dapat dilihat alternatif penanganan menunjukkan kinerja yang cukup baik dibandingkan sebelum perencanaan dimana diperoleh nilai DS 0.84 pada masing-masing pendekat. Nilai tersebut telah memenuhi standar nilai derajat kejenuhan. 
Adapun nilai waktu hijau dan waktu siklusnya adalah sebagai berikut :

Fase $1:$ waktu hijau $=21$ detik

Fase 2: waktu hijau $=39$ detik

Fase 3 : waktu hijau $=20$ detik

Waktu siklus : 96 detik

Diagram fase dapat dilihat pada gambar dibawah

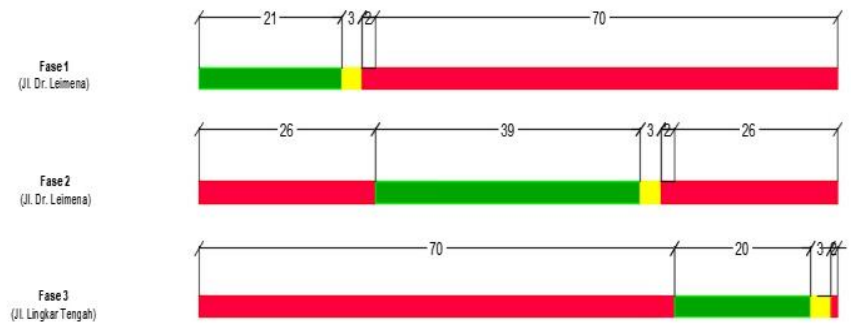

Gambar 3.7. Hasil Analisis Simpang

Dari hasil analisis dan perhitungan tersebut diperoleh waktu siklus untuk membandingkan hasil rekayasa sebelum dan setelah pemasangan traffic light menggunakan PTV Vissim yang dapat dilihat pada gambar 4.

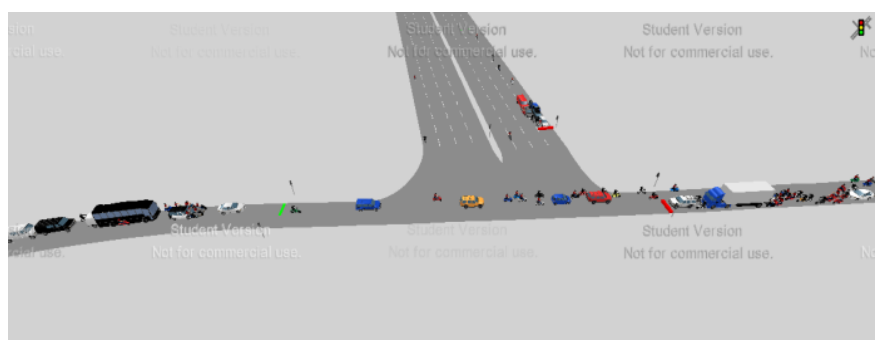

Gambar 3. 8 Setelah Rekayasa Pemasangan Traffic Light

4. Dampak Rekayasa bagi Pengguna Jalan

Dampak rekayasa bagi pengguna jalan menggunakan alternatif metode penutupan jembatan yang dapat diketahui dari waktu tempuh kendaraan melalui jalan tersebut. Dari data yang diperoleh menggunakan perangkat lunak PTV VISSIM 9. Waktu tempuh sebelum dan setelah dilakukan rekayasa dan setelah rekayasa dapat dilihat tabel 3.17

\begin{tabular}{|c|c|c|c|c|}
\hline \multirow{2}{*}{ Hasil } & \multirow{2}{*}{ Nama Jalan } & \multicolumn{3}{|c|}{ Waktu Tempuh } \\
\cline { 3 - 5 } & & pagi & siang & sore \\
\hline \multirow{2}{*}{$\begin{array}{c}\text { Sebelum } \\
\text { rekayasa }\end{array}$} & Leimena & 71.53 & 41.21 & 151.71 \\
\cline { 2 - 5 } & MRR Keluar & 37.06 & 39.31 & 109.47 \\
\hline Setelah rekayasa & Leimena & 37.77 & 38.28 & 36.61 \\
\hline
\end{tabular}

Sumber : Hasil Perhitungan, 2020

Dari tabel 3.17 Dapat dilihat bahwa setelah dilakukannya rekayasa, waktu tempuh pengedara menjadi meningkat dari arah keluar Jl. Lingkar Tengah dan Jl. Dr. Leimena.

Tabel. 3.18. Rasio Analisis Antrian Kendaraan Sebelum dan Setelah Rekayasa

\begin{tabular}{|c|c|c|c|c|c|c|}
\hline \multirow[t]{2}{*}{ Lokasi } & \multirow[t]{2}{*}{ Periode } & $\begin{array}{l}\text { Total } \\
\text { Arus } \\
\end{array}$ & $\begin{array}{c}\text { Rata-rata } \\
\text { Waktu }\end{array}$ & $\begin{array}{c}\text { Tingkat } \\
\text { Pelayanan }\end{array}$ & $\begin{array}{c}\text { Rasio } \\
\text { Antrian }\end{array}$ & \multirow[t]{2}{*}{ Keterangan } \\
\hline & & $(Q)(\lambda)$ & (detik) & $(\mu)$ & (p) & \\
\hline \multirow{3}{*}{ Leimena } & Pagi & 791 & 71.53 & 50.329 & 15.72 & \multirow{6}{*}{$\begin{array}{l}\text { Sebelum } \\
\text { Rekayasa }\end{array}$} \\
\hline & Siang & 1004 & 41.21 & 87.357 & 11.49 & \\
\hline & Sore & 1986 & 151.71 & 23.729 & 83.69 & \\
\hline \multirow{3}{*}{$\begin{array}{l}\text { MRR } \\
\text { Keluar }\end{array}$} & Pagi & 705 & 37.06 & 97.140 & 7.26 & \\
\hline & Siang & 891 & 39.31 & 91.580 & 9.73 & \\
\hline & Sore & 1885 & 109.47 & 32.886 & 57.32 & \\
\hline \multirow{3}{*}{ Leimena } & Pagi & 791 & 37.77 & 95.302 & 8.30 & \multirow{6}{*}{$\begin{array}{c}\text { Setelah } \\
\text { Rekayasa }\end{array}$} \\
\hline & Siang & 1004 & 38.28 & 94.035 & 10.68 & \\
\hline & Sore & 1986 & 36.61 & 98.335 & 20.20 & \\
\hline \multirow{3}{*}{$\begin{array}{c}\text { MRR } \\
\text { Keluar }\end{array}$} & Pagi & 705 & 31.51 & 114.256 & 6.17 & \\
\hline & Siang & 891 & 33.40 & 107.800 & 8.27 & \\
\hline & Sore & 1885 & 32.33 & 111.340 & 16.93 & \\
\hline
\end{tabular}

Sumber : Hasil Perhitungan, 2020

Dari Tabel 3.18 rasio intensitas antrian pada arah keluar Jl. Lingkar Tengah dan Jl. Dr. Leimena sebesar $(\rho)>1,0$; artinya terjadi antrian akibat simpang. Setelah dilakukanya rekayasa terjadi penurunan panjang antrian.

Adapun persen (\%) peningkatan waktu tempuh yang terjadi setelah dilakukannya rekayasa, maka digunakan persamaan (persentase) \%:

$$
\begin{aligned}
\text { Persentase } \% & =\frac{(\text { awal-akhir })}{\text { awal }} \times 100 \% \\
& =\frac{(88.15-37.55}{88.15} \times 100 \% \\
& =47.68 \%
\end{aligned}
$$

Tabel 3.19 Intensitas Peningkatan Waktu tempuh setelah rekayasa

\begin{tabular}{|c|c|c|c|c|}
\hline Lokasi & Waktu & $\begin{array}{c}\text { Sebelum } \\
\text { Rekayasa }\end{array}$ & $\begin{array}{c}\text { Setelah } \\
\text { Rekayasa }\end{array}$ & $\begin{array}{c}\text { Persentase } \\
(\%)\end{array}$ \\
\hline \multirow{2}{*}{$\begin{array}{c}\text { MRR } \\
\text { Keluar }\end{array}$} & Pagi & 37.06 & 33.48 & \multirow{2}{*}{47.68} \\
\cline { 2 - 4 } & Siang & 39.31 & 34.79 & \\
\cline { 2 - 4 } & Sore & 109.47 & 33.71 & \multirow{2}{*}{57.40} \\
\hline \multirow{3}{*}{ Leimena } & Pagi & 71.53 & 37.46 & \\
\cline { 2 - 4 } & Siang & 41.21 & 38.28 & \\
\cline { 2 - 4 } & Sore & 151.71 & 36.61 & \\
\hline
\end{tabular}

Sumber : Hasil Perhitungan, 2020

Dari Tabel 3.19 diperoleh nilai persentase peningkatan waktu tempuh setelah dilakukannya rekayasa pada Jl. Dr. Leimena. 


\section{Kesimpulan}

\section{A. Kesimpulan}

Berdasarkan hasil penelitian yang dilakukan, maka dapat disimpulkan sebagai berikut :

1. Kinerja Jl. Lingkar Tengah diperoleh nilai derajat kejenuhan (DS) sebesar 0,12 dengan tingkat pelayanan jalan (LoS) A, sedangkan berdasarkan kecepatan rata-rata kendaraan pada saat jam sibuk diperoleh indeks pelayanan tingkat $\mathrm{D}$ (kecepatan rata-rata $\geq 23 \mathrm{~km} / \mathrm{jam}$ ).

2. Rekayasa yang dapat dilakukan untuk Jl. Lingkar Tengah Makassar akibat Jl. Dr. Leimena menggunakan simulasi pemodelan PTV Vissim dengan melakukan dua metode yaitu penutupan jembatan di Jl.Dr. Leimena akibat tingginya volume kendaraan yang melawan arus dari Jl. Dr. Leimena ke Jl. Lingkar Tengah Makassar. Metode kedua yaitu Perencanaan Traffic Light pada kawasan simpang.

3. Dampak setelah dilakukannya rekayasa lalu lintas terhadap pengguna jalan yaitu waktu tempuh pengedara melintasi jalan tersebut mengalami peningkatan waktu tempuh pada arah keluar Jl. Lingkar Tengah sebelum dilakukannya rekayasa sebesar 61.95 detik sedangkan waktu tempuh setelah dilakukannya rekayasa sebesar 32.41 detik artinya waktu tempuh pada ruas jalan tersebut mengalami peningkatan sebesar 47.68\% dan waktu tempuh pada ruas Jl. Dr. Leimena sebelum dilakukannya rekayasa sebesar 88.15 detik sedangkan waktu tempuh setelah dilakukannya rekayasa sebesar 37.56 detik artinya waktu tempuh pada ruas jalan tersebut mengalami peningkatan sebesar $57.40 \%$.

\section{B. Saran}

Dari hasil penelitian yang diperoleh saran yang dapat diberikan adalah sebagai berikut :

1. Perlunya penegasan pemerintah terkait pihak yang berwenang pada Jl. Lingkar Tengah Makassar.

2. Perlunya penegasan petugas lalu lintas dan instansi untuk melakukan sosialisasi kepada masyarakat.

3. Perlunya Penempatan pos penjaga di titik Jl.Dr. Leimena - Jl. Lingkar Tengah.

4. Melakukan alternatif rekayasa lain seperti pelebaran jalan pada Jalan Dr. Leimena agar konflik pada simpang Jl. Lingkar Tengah- Jl. Dr. Leimena bisa lebih berkurang.

5. Penambahan fasilitas-fasilitas pada Jl. Lingkar Tengah, seperti lampu penerangan disepanjang Jl. Lingkar Tengah

6. Perlunya dilakukan penelitian lebih lanjut mengenai perbaikan geometrik jalan pada ruas Jl. Dr. Leimena.

\section{Ucapan Terima Kasih}

Puji syukur senantiasa penulis panjatkan kepada Allah SWT yang telah melimpahkan Rahmat dan Hidayah-Nya kepada penulis sampai saat ini dan terimakasih pula kepada :

1. Keluarga penulis, terkhusus kepada kedua orang tua, wali dan saudara-saudara.

2. Bapak Prof. Ir. Muhammad Anshar, M.Si., Ph.D selaku Direktur Politeknik Negeri Ujung Pandang.

3. Bapak Dr. Andi Muhammad Subhan, S.T., M.T. selaku Ketua Jurusan Teknik Sipil Politeknik Negeri Ujung Pandang.

4. Bapak Indra Mutiara, S.T.,M.T. selaku Ketua Program Studi D4 Jasa Konstruksi Sipil.

5. Bapak Ir. Bustamin Abdul Razak, M.T. selaku pembimbing 1 dan Ibu Aisyah Zakaria, ST., MT. selaku pembimbing 2 .

6. Seluruh dosen, Staf dan Karyawan Jurusan Teknik Sipil Politeknik Negeri Ujung Pandang.

7. Teman-teman khususnya kelas 4A D4 Jasa Konstruksi Sipil yang telah memberikan dukungan dan bantuan

8. Dan semua pihak yang tidak sempat penulis sebutkan namanya.

\section{Daftar Pustaka}

[1] Afdhal, Chairil. 2014. Definisi Rekayasa Lalu Lintas (online) (cyrilengineering.blogspot.com/2014/07/definisi-rekayasa-lalulintas.html) diakses 22 Agustus 2020.

[2] Akmaluddin dan Indrawan, A.H. 2018. Evaluasi Kinerja Ruas Jalan Satu Arah dengan Metode MKJI 1997 dan Sofware VISSIM. Laporan Tugas Akhir. Makassar: Politeknik Negeri Ujung Pandang.

[3] Alamsyah, Alik, Ansyori. 2005. Rekayasa Lalulintas. Universitas Muhammadiyah Malang Press: Malang

[4] Alfidzal, M.R. dan Hasriayu. 2019. Optimalisasi Kinerja Simpang Tak Bersinyal Jl. Batua Raya - Jl. Borong Raya - Jl. Toddopuli Raya Timur Di Kota Makassar. Skripsi. Makassar : Politeknik Negeri Ujung Pandang

[5] Alifian, D.C., Thoha, M.A.I., Sulistio, H. \& Wicaksono,A. 2014. Kajian Manajemen Lalu Lintas Jaringan Jalan di Kawasan Terusan Ijen Kota Malang. Jurnal. Malang. Universitas Brawijaya. 
[6] Andriansyah. 2015. Manajemen Transportasi dalam Kajian Teori. Jakarta.

[7] Arjuna dan Wulandari, Riska. 2018. Analisis Kemacetan dan Tingkat Pelayanan Ruas Jalan Sultan Alauddin Makassar. Skripsi. Makassar : Politeknik Negeri Ujung Pandang.

[8] Badan Pusat Statistik Provinsi Sulawesi Selatan, 2019. Provinsi Sulawesi Selatan Dalam Angka 2019, BPS Provinsi Sulawesi Selatan

[9] Cahyanto, R. 2013. Evaluasi Kinerja Jalan dan Mengindentifikasi Penyebab Kemacetan (Studi Kasus : Ruas Jalan Lenteng Agung, Jakarta Selatan) Skripsi. Bandar Lampung : Universitas Lampung.

[10] Direktorat Jendral Bina Marga. 1997. Manual kapasitas jalan indonesia (MKJI). Jakarta: Departemen PU.

[11] Direktorat Jendral Bina Marga. 1997.Tata Cara Perencanaan Geometrik Jalan Antar Kota. Jakarta: Departemen PU.

[12] Fatin, Nur. 2014. Seputar Pengertian Transportasi, (online), (http://seputarpengertian.blogspot.com/2014/03/seputarpengertian-transportasi.html) diakses 22 Agustus 2020.

[13] Hobbs, F. D. 1995. Perencanaan dan Teknik Lalu Lintas. Yogyakarta: Gajah Mada University Press.

[14] Kementerian PU . 2014. Pedoman Kapasitas Jalan Indonesia. Jakarta

[15] Morlok, E. K. 1991. Pengantar Teknik dan Perencanaan Transportasi. Jakarta: Erlangga.

[16] Muhtadi A. 2010. Analisis Kapasitas, Tingkat Pelayanan, Kinerja dan Pengaruh Pembuatan Median Jalan.Jurnal Neutron volume 10, No.1 - Pebruari $2010 \mathrm{Hal} 43$ - 54.

[17] Mulyadi, Agus. 2012. Analisis Kapasitas Simpang Bersinyal Terhadap Larangan Belok Kiri Langsung (Studi Kasus: Simpang
Jl. Mt. Haryono, Jl. Sao-Sao Dan Jl. Sorumba). Skripsi. Kendari: Universitas Haluoleo.

[18] Peraturan Pemerintah Republik Indonesia Nomor 32 Tahun 2011 Tentang Manajemen dan Rekayasa, Analisis Dampak, serta Manajemen Kebutuhan Lalu Lintas. 2011.Jakarta.

[19] Peraturan Pemerintah Republik Indonesia Nomor 43 Tahun 1993 Tentang Prasarana dan Lalu Lintas Jalan. 1993.Jakarta.

[20] Purwanto, Edi. 2013. Karakteristik Arus Lalu Lintas. Pembagian Kecepatan, (online) (https://www.slideshare.net/bangkitbayu/karakteristik-arus-lalulintas) diakses 15 Januari 2020.

[21] Putri, Nurjannah Haryanti. 2015. Mikrosimulasi Mixed Traffic Pada Simpang Bersinyal Dengan Perangkat Lunak Vissim (Studi Kasus: Simpang Tugu, Yogyakarta). Skripsi. Yogyakarta: Universitas Gadjah Mada.

[22] Saputra, Fahmi Pratama. 2016. Analisis dan Optimasi Kinerja Simpang Bersinyal Di Jl. Gunung Bawakaraeng Jl.Jend.Sudirman Berbasis Micro -Simulasi. Makassar: Universitas Hasanuddin

[23] Ulfah, Marissa. 2017. Mikrosimulasi Lalu Lintas pada Simpang Tiga dengan Software Vissim (Studi Kasus Simpang Jl. A.P Pettarani - J. Let. Jend. Hertasning dan simpang Jl. A.P. Pettarani - Jl. Rappocini Raya). Skripsi. Makassar: Uniersitas Hasanuddin.

[24] Wesnawa, I.G.A dan Treman, Wayan. 2014. Variasi Kemacetan Lalu Lintas Di Kota Singaraja. Jurnal Pendidikan Geografi Undiksha. Vol. 2, No.1

[25] Zakaria, Aisyah. 2019. Analisis Kinerja Jalan Akibat Kendaraan Yang Memutar (U-Turn) Di Jalan Perintis Kemerdekaan. Prosiding Seminar Nasional Penelitian \& Pengabdian Kepada Masyarakat, MMIXIX. 148-153. 